\title{
KINERJA BIDAN DALAM DETEKSI DINI PENYIMPANGAN TUMBUH KEMBANG ANAK
}

\author{
(Midwife's Performance On Early Detection Of Deviations In Child's Growth And \\ Development)
}

\author{
Sri Utami*, Nursalam**, Rachmat Hargono***, Rekawati Susilaningrum* \\ *Poltekkes Kemenkes Surabaya, Jl. Pucang Jajar Tengah no. 56 Surabaya, 60282 \\ ***Fakultas Keperawatan Universitas Airlangga \\ *** Fakultas Kesehatan Masyarakat Universitas Airlangga \\ Email: bu.sri.utami67@gmail.com
}

\begin{abstract}
ABSTRAK
Introduction: Anak merupakan generasi penerus bangsa, mereka harus dapat tumbuh dan berkembang secara optimal. Salah satu upaya yang dapat dilakukan adalah melalui deteksi dini penyimpangan tumbuh kembang anak. Tujuan penelitian ini adalah menyusun model peningkatan kinerja bidan melalui optimalisasi strategi self leadership. Metode: jenis penelitian ini adalah obsrvasional dengan rancangan cross sectional, subyek yang diteliti adalah sebagian bidan di Puskesmas wilayah kerja Dinas Kesehatan Kota Surabaya, dipilih secara propotional random sampling, sejumlah 222 responden. Variabel eksogennya adalah job design, riwayat pelatihan DDTK, strategi self leadership, kemampuan bidan, aktivitas bidan dalam DDTK, varibel endogennya adalah hasil capaian bidan dalam DDTK. Analisis data menggunakan metode Partial Least Square (PLS). Hasil: dari hasil analisis inner model diperoleh nilai T-statistik pada pengaruh strategi self leadership terhadap peningkatan kemampuan bidan, pengaruh kemampuan terhadap peningkatan kinerja aktivitas, strategi self leadership terhadap peningkatan kinerja aktivitas dan terhadap peningkatan hasil capaian dalam deteksi dini penyimpangan tumbuh kembang didapatkan niali T-statistik lebih besar dari nilai T-tabel $(1,96)$. Sedangkan untuk training SDIDTK tidak berpengaruh terhadap peningkatan kemampuan bidan, tidak berpengaruh terhadap peningkatan kinerja aktivitas bidan, begitu juga job design tidak terdapat pengaruh terhadap peningkatan kemampuan bidan dan terhadap peningkatan kinerja aktivitas bidan dalam deteksi dini penyimpangan tumbuh kembang anak karena diperoleh nilai T-statistik lebih kecil dari T-tabel $(<1,96)$. Diskusi: Optimalisasi kemampuan self-leadership bidan merupakan faktor yang perlu diperhatikan sebagai upaya peningkatan kinerja bidan dalam deteksi dini pemyimpangan tumbuh kembang anak.
\end{abstract}

Kata Kunci: tumbuh kembang anak, job desain, training , strategi self leadership, kinerja.

\section{ABSTRACT}

Introduction: Children are the future of a nation.They should be able to grow and develop optimally. One effort that can be done to help children grow and develop optimally is through an early detection of deviationsin child's growth. The purpose of this study was to develop a model of midwife performance improvement through the optimization of self leadership strategy. Method: This study was an observational study with cross sectional design. The subjects were 222 midwives working at the health center services in the area of Surabaya Health Department taken by using proportional random sampling technique. Exogenous variables were job design, history of training of early detection of deviationsin child's growth, self leadership strategy, midwife skill, midwife activity in early detection of deviationsin child's growth, andendogenous variable was midwife performance in early detection of deviationsin child's growth. Data were analyzed using Partial Least Square (PLS). Result: The result of inner model analysis showed that the value of T-statistic of the influence of self leadership strategyon midwife performance improvement, the influence of midwife skill on activity performance improvement, the influence of self leadership strategyon activity performance improvement and on midwife performance improvement was higher than T-table (1.96). Whereas, training of early detection of deviationsin child's growth did not influence midwife skill improvement since the value of T-statistic was lower than T-table $(<1.96)$. In addition, there was also no influence of job design on midwife skill improvement and on midwife activity performance improvement in early detection of deviationsin child's growth. Discussion: Optimization of midwife self-leadership ability is a factor to be considered as an effort to improve the performance of midwives in early detection of deviationsin child's growth.

Key words: child's growth and develoment, job desain, training, self leadership strategy, performance.

\section{PENDAHULUAN}

Anak harus tumbuh dan berkembang secara optimal sampai dewasa agar dia dapat menjadi generasi penerus bangsa yang berkualitas. Mengingat jumlah balita sangat besar, yaitu sekitar 10 persen dari seluruh populasi, maka tumbuh kembang balita di Indonesia perlu mendapat perhatian serius (Depkes. RI., 2007). Deteksi dini penyimpangan tumbuh kembang anak merupakan upaya yang sangat penting untuk dilakukan mulai dari tingkat keluarga, masyarakat dan tingkat pelayanan dasar, hal ini bertujuan untuk mengenali sedini 
mungkin terjadinya gangguan pertumbuhan dan perkembangan anak (Depkes. RI., 2007).

Target cakupan Deteksi Dini Tumbuh Kembang (DDTK) anak balita dan anak pra sekolah telah ditetapkan sebesar 90\%. Ketetapan tersebut sesuai dengan Surat Keputusan Menteri Kesehatan RI No. 1457/Menkes/SK/X/2003 tentang Standar Pelayanan minimal (SPM) Bidang Kesehatan Di Kabupaten/Kota Bab II pasal 2 butir b. Di Surabaya belum semua Puskesmas mencapai pelaksanaan deteksi tumbuh kembang anak sesuai target. Tahun 2011 dari 60 Puskesmas masih ada 46 (77\%) Puskesmas yang capaian DDTK pada balita dan 38 (63\%) Puskesmas pada anak pra sekolah yang masih dibawah target. Pada tahun 2012 dari 62 Puskesmas, masih ada 47 (76\%) Puskesmas yang capaian DDTK pada balita dan 36 (58\%) Puskesmas pada anak pra sekolah yang masih dibawah target. Pada tahun 2013 dari 62 Puskesmas, masih ada 31 (50\%) Puskesmas yang capaian DDTK pada balita dan 25 (40\%) Puskesmas pada anak pra sekolah yang masih dibawah target (Dinas Kesehatan Kota Surabaya 2013; Dinkes Propinsi Jawa Timur 2012; Dinas Kesehatan Kota Surabaya 2012; Dinas Kesehatan Kota Surabaya 2010)(Dinas Kesehatan Kota Surabaya, 2011, 2012, 2013)

Beberapa faktor yang mempengaruhi kinerja, meliputi faktor organisasi, faktor ini terdiri dari sistem perhargaan, penetapan tujuan termasuk di dalamnya adalah visi dan misi organisasi, sistem seleksi pegawai, adanya pelatihan dan pengembangan dari sumber daya yang ada. Faktor berikutnya adalah faktor karakteristik pekerjaan, faktor ini meliputi desain pekerjaan, jadwal kerja, umpan balik tujuan hasil pekerjaan.

Salah satu upaya untuk meningkatkan kinerja bidan dapat dilaksanakan melalui pendekatan self-leadership. Self-leadership merupakan faktor penting dalam mengoptimalkan kemampuan diri bidan, karena dengan kemampuan self-leadership akan meningkatkan kepercayaan diri bidan terhadap kemampuannya dalam melaksanakan tugastugasnya dan hal ini dapat meninkatkan berbagai faktor yang berpengaruh terhadap peningkatan kinerja. Tujuan penelitian ini adalah menyusun model peningkatan kinerja bidan melalui optimalisasi strategi self leadership.

\section{BAHAN DAN METODE}

Jenis penelitian ini adalah analitik observasional, dengan pendekatan crossectional, Waktu penelitian mulai Januari 2015-Juni 2016. Subyek dalam penelitian ini adalah sebagian bidan di Puskesmas Wilayah kerja Dinas Kesehatan Kota Surabaya, dengan kriteria inklusi: Pendidikan minimal Diploma III Kebidanan, pelaksana dalam kegiatan deteksi dini tumbuh kembang anak, bersedia menjadi responden. sebesar 222bidan yang tersebar di 43 Puskesmas, tehnik pengambilan sampel menggunakan proposionalrandom sampling. Variabel eksogennya adalah job design, riwayat pelatihan DDTK, strategi self leadership, kemampuan bidan, variabel endogennya adalah aktivitas dan hasil capaian bidan dalam DDTK. Intrumen yang digunakan adalah kuesioner dan untuk kinerja menggunakan lembar pengumpul data. Analisis data menggunakan Structural Equation Modelling (SEM) berbasis variance yang disering disebut dengan Partial Least Square(PLS).

\section{HASIL}

Hasil penelitian ini menyajikan data karakteristik responden dan Deskripsi variabel sertahasil analisis inferensial. Hasil penelitian selengkapnya dapat dilihat pada tabel berikut. Berdasarkan tabel 1 dapat dijelaskan bahwa, beban kerja bidan mayoritas dalam kategori cukup. Waktu yang dimiliki untuk melaksanakan pekerjaannya mayoritas dalam kategori cukup, beban kerja yang dirasakan bidan mayoritas dalam kategori berat, keterampilan yang dibutuhkan untuk menyelesaikan tugas mayoritas dalam kategori cukup.

Variasi dalam pekerjaan yang dilakukan mayoritas dalam kategori banyak variasi, dan mayoritas membutuhkan pemikiran yang cukup banyak. Berdasarkan tabel 2 dapat dijelaskan bahwa mayoritas bidan belum pernah mengikuti pelatihan tentang DDTK, dan mayoritas terlibat dalam kegiatan DDTK antara 6-10 tahun. Berdasarkan tabel 3 diketahui bahwa mayoritas bidan dengan strategi self-leadership dalam kategori cukup yang ditunjukkan oleh $(>50 \%)$ bidan memiliki strategi berfokus perilaku, strategi imbalan alami, strategi pola berpikir konstruktif dalam kategori cukup 
Kinerja Bidan Dalam Deteksi Dini (Sri Utami, dkk)

$\underline{\text { Tabel 1. Diskripsi Karakteristik Pekerjaan atau Job Desain }}$

\begin{tabular}{lllrr}
\hline No. & Indikator & kategori & Frekuensi & \multicolumn{1}{c}{} \\
\hline 1. & Beban kerja & & 36 & 16,2 \\
& & Sedikit & 165 & 74,3 \\
& & cukup & 21 & 9,5 \\
\hline 2. & Butuh waktu & banyak & 52 & 23,4 \\
& & kurang & 152 & 68,5 \\
& & Cukup & 18 & 8,1 \\
\hline 3. & Beban fisik & Banyak & 8 & 3,6 \\
& & Ringan & 64 & 28,8 \\
& & Sedang & 150 & 67,6 \\
\hline 4. & Kebutuhan keterampilan & berat & 9 & 4,1 \\
& & sedikit & 176 & 79,3 \\
& & Cukup & 37 & 16,7 \\
\hline 5. & Variasi pekerjaan & Banyak & 4 & 1,8 \\
& & Kurang & 41 & 18,5 \\
& & Cukup & 177 & 79,7 \\
\hline 6. & Butuh pemikiran & banyak & 12 & 5,4 \\
& & Sedikit & 175 & 78,8 \\
\hline
\end{tabular}

Tabel 2. Deskripsi Riwayat Training

\begin{tabular}{lllrr}
\hline No. & Indikator & kategori & Frekuensi & \\
& & & \multicolumn{2}{c}{} \\
\hline 1. & Riwayat training & Belum pernah & 178 & 80.2 \\
& & Sudah pernah & 44 & 19.8 \\
\hline 2. & Lama ketrerlibatan dalam DDTK & $3-5$ tahun & 101 & 45.5 \\
& & $6-10$ tahun & 107 & 48.2 \\
& & $11-15$ tahun & 10 & 4.5 \\
& & $16-20$ tahun & 4 & 1.8 \\
\hline
\end{tabular}

Tabel 3. Deskripsi Self leadership

\begin{tabular}{lllrr}
\hline No. & Indikator & kategori & \multicolumn{2}{c}{ Frekuensi } \\
& & & \multicolumn{2}{c}{} \\
\hline 1. & Behavior Focused Strategies & Kurang & 23 & 10.4 \\
& & Cukup & 121 & 54.5 \\
& & Baik & 78 & 35.1 \\
\hline 2. & Natural Reward Strategies & Kurang & 16 & 7.2 \\
& & Cukup & 125 & 56.3 \\
& & Baik & 81 & 36.5 \\
\hline 3. & Constuctive Thought Pattern Strategies & Kurang & 18 & 8.1 \\
& & Cukup & 132 & 59.5 \\
& & Baik & 72 & 32.4 \\
\hline
\end{tabular}

Tabel 4. Deskripsi Kemampuan Bidan tentang Deteksi Tumbuh Kembang Anak

\begin{tabular}{lllrr}
\hline No. & Indikator & kategori & Frekuensi \\
& & & $\boldsymbol{\Sigma}$ & $\%$ \\
\hline 1 & Kemampuan deteksi pertumbuhan & Kurang & 31 & 14,0 \\
& & Cukup & 102 & 45,9 \\
& & Baik & 89 & 40,1 \\
\hline 2 & Kemampuan deteksi perkembangan & Kurang & 32 & 14,4 \\
& & Cukup & 98 & 44,1 \\
& & Baik & 222 & 41,4 \\
\hline
\end{tabular}


Tabel 5. Deskripsi aktivitas Bidan Dalam Deteksi Penyimpangan Tumbuh Kembang Anak

\begin{tabular}{|c|c|c|c|c|}
\hline \multirow[t]{2}{*}{ No. } & \multirow[t]{2}{*}{ Aktivitas bidan } & \multirow[t]{2}{*}{ Kategori } & \multicolumn{2}{|c|}{ Frekuensi } \\
\hline & & & $\Sigma$ & $\%$ \\
\hline \multirow[t]{3}{*}{1.} & \multirow[t]{3}{*}{ Deteksi penyimpangan pertumbuhan bayi } & Kadang-kadang & 3 & 1.4 \\
\hline & & Sering & 14 & 6.3 \\
\hline & & Selalu & 205 & 92.3 \\
\hline \multirow[t]{3}{*}{2.} & \multirow[t]{3}{*}{ Deteksi pertumbuhan balita dan anak pra sekolah } & Kadang-kadang & 25 & 11.3 \\
\hline & & Sering & 99 & 44.6 \\
\hline & & Selalu & 98 & 44.1 \\
\hline \multirow[t]{4}{*}{3.} & \multirow[t]{4}{*}{ Deteksi penyimpangan perkembangan bayi } & Tidak pernah & 3 & 1.4 \\
\hline & & Kadang-kadang & 40 & 18.0 \\
\hline & & Sering & 101 & 45.5 \\
\hline & & Selalu & 78 & 35.1 \\
\hline \multirow[t]{4}{*}{4.} & \multirow{4}{*}{$\begin{array}{l}\text { Deteksi penyimpangan perkembangan balita dan anak pra } \\
\text { sekolah }\end{array}$} & Tidak pernah & 2 & .9 \\
\hline & & Kadang-kadang & 50 & 22.6 \\
\hline & & Sering & 104 & 46.8 \\
\hline & & Selalu & 66 & 29.7 \\
\hline \multirow[t]{4}{*}{5.} & \multirow[t]{4}{*}{ TDL dan TDD } & Tidak pernah & 8 & 3.6 \\
\hline & & Kadang-kadang & 51 & 23.0 \\
\hline & & Sering & 98 & 44.1 \\
\hline & & Selalu & 65 & 29.3 \\
\hline \multirow[t]{4}{*}{6.} & \multirow[t]{4}{*}{ Deteksi mental emosional (MME, autis, GPPH) } & Tidak pernah & 22 & 9.9 \\
\hline & & Kadang-kadang & 81 & 36.5 \\
\hline & & Sering & 79 & 35.6 \\
\hline & & Selalu & 40 & 18.0 \\
\hline
\end{tabular}

Tabel 6. Deskripsi Hasil Capaian/Hasil Layanan Bidan Dalam Deteksi Penyimpangan Tumbuh Kembang Anak

\begin{tabular}{|c|c|c|c|c|}
\hline No. & Hasil capaian bidan & Kategori & Frekuensi & $\%$ \\
\hline \multirow[t]{3}{*}{1.} & \multirow[t]{3}{*}{ Deteksi penyimpangan pertumbuhan bayi } & Kurang & 15 & 6.8 \\
\hline & & Cukup & 58 & 26.1 \\
\hline & & Baik & 149 & 67.1 \\
\hline \multirow[t]{3}{*}{2.} & \multirow{3}{*}{$\begin{array}{l}\text { Deteksi penyimpangan pertumbuhan balita dan anak pra } \\
\text { sekolah }\end{array}$} & Kurang & 18 & 8.1 \\
\hline & & Cukup & 68 & 30.6 \\
\hline & & Baik & 136 & 61.3 \\
\hline \multirow[t]{3}{*}{3.} & \multirow[t]{3}{*}{ Deteksi penyimpangan perkembangan bayi } & Kurang & 22 & 9.9 \\
\hline & & Cukup & 60 & 27.0 \\
\hline & & Baik & 140 & 63.1 \\
\hline \multirow[t]{3}{*}{4.} & \multirow{3}{*}{$\begin{array}{l}\text { Deteksi penyimpangan perkembangan balita dan anak pra } \\
\text { sekolah }\end{array}$} & Kurang & 29 & 13.1 \\
\hline & & Cukup & 64 & 28.8 \\
\hline & & Baik & 129 & 58.1 \\
\hline \multirow[t]{3}{*}{5.} & \multirow[t]{3}{*}{ Deteksi TDD dan TDL } & Kurang & 72 & 32.4 \\
\hline & & Cukup & 39 & 17.6 \\
\hline & & Baik & 111 & 50.0 \\
\hline \multirow[t]{3}{*}{6.} & \multirow[t]{3}{*}{ Deteksi MME, autis, GPPH } & Kurang & 117 & 52.7 \\
\hline & & Cukup & 34 & 15.3 \\
\hline & & Baik & 71 & 32.0 \\
\hline
\end{tabular}

Berdasarkan tabel 5 diketahui bahwa aktivitas bidan dalam deteksi penyimpangan pertumbuhan pada bayi mayoritas $(92,3 \%)$ bidan selalu melakukan setiap bulan sesuai dengan umur anak. sedangkan untuk aktivitas bidan dalam deteksi dini penyimpangan pertumbuhan pada balita dan anak pra sekolah, deteksi penyimpangan perkembangan, tes daya dengar, tes daya lihat, deteksi MME, autis, maupun GPPH pada bayi, balita dan anak pra 
sekolah sering dilakukan tetapi belum selalu sesuai jadwal yang dibutuhkan anak. Berdasarkan tabel 6 diketahui bahwa mayoritas (sekitar 50\%-67,1\%) bidan telah melakukan deteksi dini penyimpangan pertumbuhan, penyimpangan perkembangan, tes daya dengar, tes daya lihat pada $\geq 90 \%$ bayi, balita dan anak prasekolah dalam kategori baik. Sedangkan pelayanan deteksi MME, autis, GPPH mayoritas (52.7) bidan dalam kategori kurang, artinya mayoritas bidan dapat melakukan deteksi pada $\leq 45 \%$ bayi, balita dan anak prasekolah yang ada di wilayah kerjanya. Selanjutnya untuk data di analisis dengan menggunakan SEM-PLS. Terdapat dua pengujian mendasar, yaitu pengujian model pengukuran (outer model), dan pengujian model struktural (inner model).

\section{Tahap model Pengukuran (Outer Model)}

Hasil pengujian model pengukuran (outer model) pada pengujian validitas konvergen didapatkan 4 indikator dari faktor job design yaitu indikator beban kerja, kebutuhan waktu, beban fisik, dan variasi pekerjaan diperoleh nilai faktor loading kurang dari 0,5 sehingga indikator tersebut dinyatakan tidak valid mengukur konstraknya. sedangkan untuk indikator dari masing-masing indikator dari kontruks atau variabel yang lainnya memiliki nilai loading faktor lebih besar dari 0,5 yang berarti semua indikator tersebut dinyatakan valid dapat mengukur konstruknya.

Hasil pengujian menunjukkan bahwa reliabilitas konstruk (variabel) seluruh variabel memiliki nilai composite reliability lebih besar dari 0,7 . Sehingga reliabel dinyatakan semua variabel tersebut reliabel.

Tabel 7. Analisis Model Pengukuran (Outer Model)

\begin{tabular}{lllll}
\hline Variabel & Dimensi/ & Faktor & Faktor & Keterangan \\
Laten/Kontruk & Indikator & $\begin{array}{l}\text { loading } \\
\text { tahap 1 }\end{array}$ & $\begin{array}{l}\text { loading } \\
\text { tahap2 }\end{array}$
\end{tabular}

\begin{tabular}{|c|c|c|c|c|}
\hline \multirow[t]{6}{*}{ Job design } & Beban kerja & 0.45 & & tidak valid \\
\hline & Kebutuhan Waktu & 0.49 & & tidak valid \\
\hline & Beban fisik & -0.73 & & tidak valid \\
\hline & keterampilan & 0.67 & 0.89 & valid \\
\hline & variasi & -0.48 & & tidak valid \\
\hline & Butuh pemikiran & 0.73 & 0.92 & valid \\
\hline \multirow[t]{2}{*}{ Training SDIDTK } & Lama terlibat DDTK & 0.94 & 1.00 & valid \\
\hline & Pelatihan DDTK & 0.58 & & tidak valid \\
\hline \multirow{3}{*}{$\begin{array}{l}\text { Strategi Self } \\
\text { Leadership }\end{array}$} & Behavior focused & 0.92 & 0.92 & valid \\
\hline & Constructive & 0.91 & 0.92 & valid \\
\hline & natural reward & 0.91 & 0.91 & valid \\
\hline \multirow[t]{2}{*}{ KemampuanBidan } & Deteksi perkembangan & 0.98 & 0.98 & valid \\
\hline & Deteksi pertumbuhan & 0.98 & 0.98 & valid \\
\hline \multirow[t]{4}{*}{ KinerjaAktivitas } & deteksi masalah emosi & 0.77 & 0.77 & valid \\
\hline & Deteksi perkembang & 0.84 & 0.84 & valid \\
\hline & TDD dan TDL & 0.81 & 0.82 & valid \\
\hline & Deteksi pertumbuhan & 0.74 & 0.74 & valid \\
\hline \multirow{3}{*}{$\begin{array}{l}\text { Strategi Self } \\
\text { Leadership }\end{array}$} & Behavior focused & 0.92 & 0.92 & valid \\
\hline & Constructive & 0.91 & 0.92 & valid \\
\hline & natural reward & 0.91 & 0.91 & valid \\
\hline \multirow[t]{4}{*}{ Hasilcapaian } & deteksi masalah emosi & 0.69 & 0.69 & valid \\
\hline & Deteksi perkembang & 0.8427 & 0.84 & valid \\
\hline & TDD dan TDL & 0.7841 & 0.78 & valid \\
\hline & Deteksi pertumbuhan & 0.8186 & 0.82 & valid \\
\hline
\end{tabular}




\section{Tahap Structural Model}

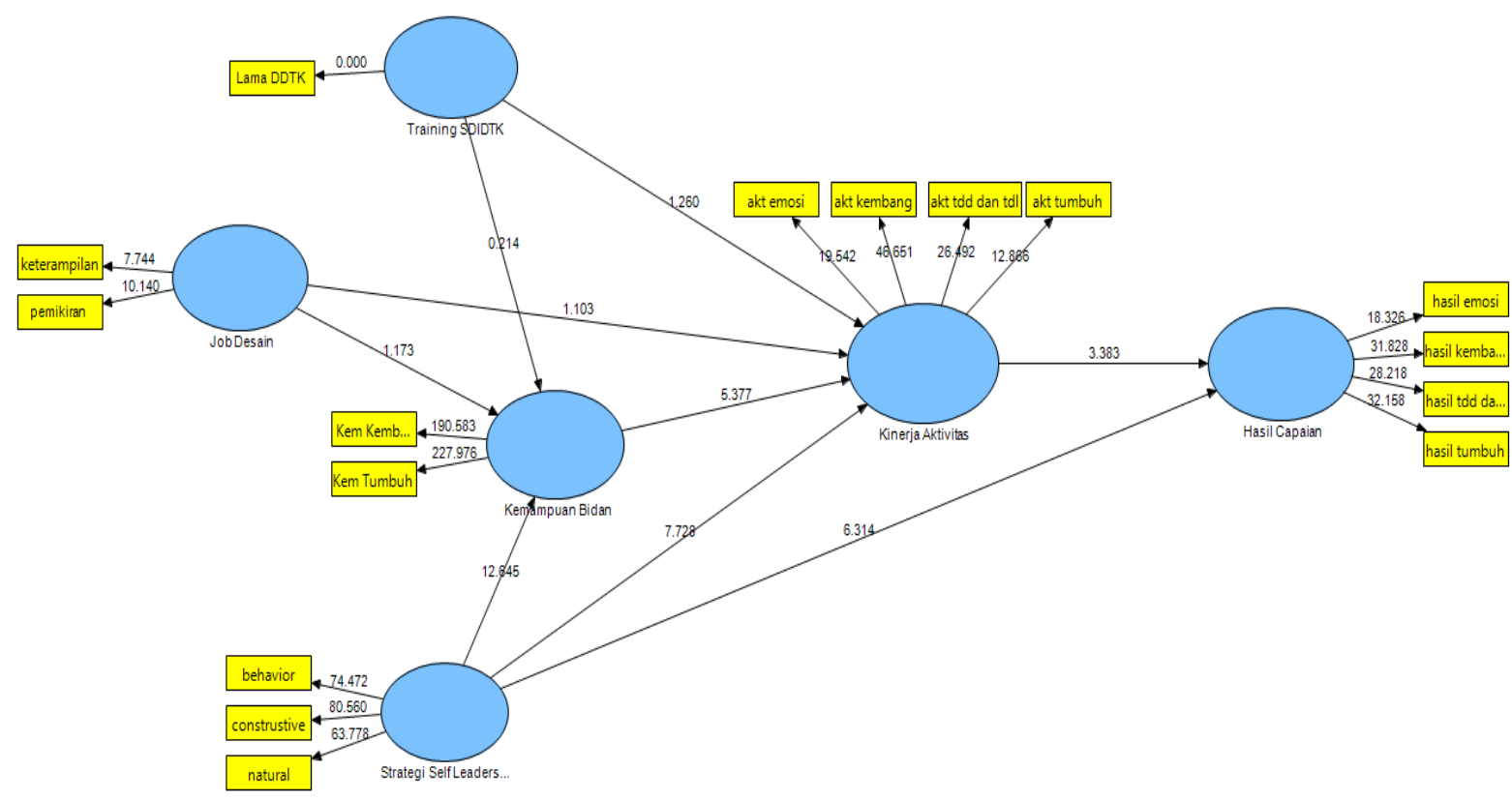

Gambar 1. Model Peningkatan Kinerja Bidan melalui (model awal)

Tabel 8. Nilai Koefisien Estimate Antar Variabel

\begin{tabular}{|c|c|c|c|}
\hline Hubunganantarvariabel & $\begin{array}{c}\text { Original } \\
\text { Sample } \\
(\mathbf{O})\end{array}$ & $\begin{array}{c}\text { T Statistics } \\
(\mid \mathbf{O} / \mathbf{S T E R R})\end{array}$ & PenerimaanHipotesis \\
\hline Training SDIDTK -> Kemampuan Bidan & 0.0124 & 0.2144 & Ho diterima \\
\hline Job Desain -> Kemampuan Bidan & -0.0772 & 1.1732 & Ho diterima \\
\hline Job Desain -> Kinerja Aktivitas & 0.0607 & 1.1027 & Ho diterima \\
\hline Training SDIDTK -> Kinerja Aktivitas & 0.0687 & 1.2602 & Ho ditolak \\
\hline Kemampuan Bidan -> Kinerja Aktivitas & 0.2979 & 5.3766 & Ho ditolak \\
\hline Strategi Self Leadership -> Kemampuan Bidan & 0.5588 & 12.6447 & Ho ditolak \\
\hline Strategi Self Leadership -> Kinerja Aktivitas & 0.4503 & 7.7281 & Ho ditolak \\
\hline Strategi Self Leadership -> Hasil Capaian & 0.4330 & 6.3142 & 3.3834 \\
\hline Kinerja Aktivitas -> Hasil Capaian & 0.2525 & & \\
\hline
\end{tabular}

Tahap structural model ini bertujuan untuk mengetahui ada tidaknya pengaruh antar variabel. Variabel dikatakan memiliki pengaruh apabila $\mathrm{t}$ hitung lebih besar dari $\mathrm{t}$ standar. $t$ standar pada penelitian ini sebesar 1,96. Demikian juga apabila hubungan antara variabel negatif maka keputusannya adalah jika $-\mathrm{t}$ hitung lebih kecil dari $-\mathrm{t}$ Ftabel. Berdasarkan gambar 1 menunjukkan bahwa dari 9 hipotesis atau pengaruh antar variabel, terdapat 4 pengaruh antar variable yang terbukti tidak ada pengaruh karena memiliki nilai t-staatistik $<1,96$, sedangkan 5 hipotesis lainnya diterima dengan nilai t-statistik > 1,96. Hipotesis penelitian yang diterima atau Ho ditolak, adalah ada pengaruh kemampuan bidan terhadap peningkatan kinerja aktivitas, ada pengaruh kinerja aktivitas terhadap peningkatan hasil capaian, ada pengaruh Strategi Self Leadership terhadap peningkatan hasil capaian, ada pengaruh Strategi Self Leadership terhadap peningkatan kemampuan bidan dan ada pengaruh strategi self leadership terhadap peningkatan kinerja aktivitas. Sedangkan 4 Hipotesis tidak diterima atau Ho diterima yaitu tidak ada pengaruh signifikan Job Desain 


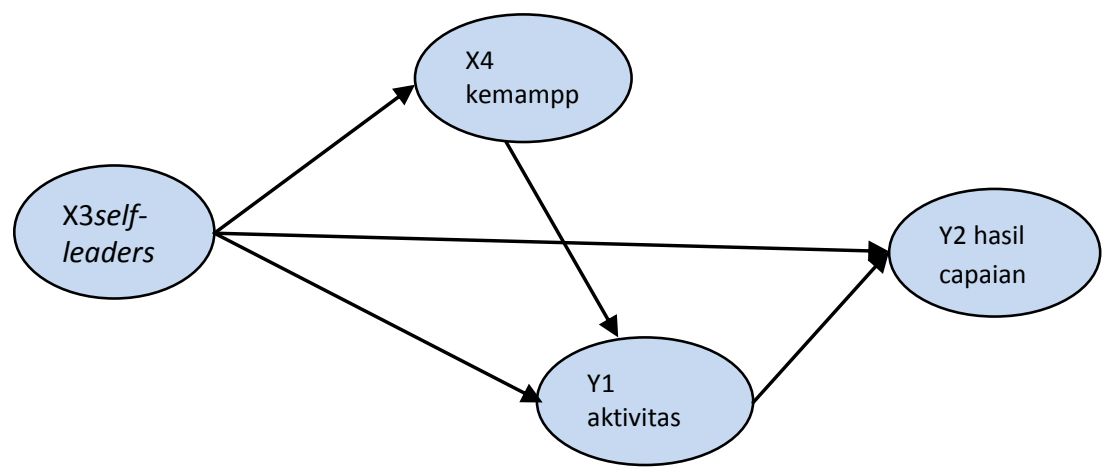

Gambar 2. Model Peningkatan Kinerja Bidan (ModelAkhir)

terhadap peningkatan kemampuan Bidan, tidak terdapat pengaruh Job Desain terhadap peningkatan kinerja Kinerja Aktivitas, tidak terdapat pengaruh riwayat training SDIDTK terhadap peningkatan kemampuan Bidan dan tidak terdapat pengaruh Riwayat training SDIDTK dengan Kinerja Aktivitas. Sehingga dari hasil tersebut di atas diperoleh hasil model akhir seperti pada gambar berikut. Nilai $\mathrm{T}$ statistik pada masing-masing pengaruh antar variabel dapat dilihat pada tabel 8 . Berdasarkan hasil pada tabel 8, maka diperoleh hasil model akhir seperti pada gambar berikut

\section{Pengujian Goodness of Fit}

Pengujian Goodness of fit dari inner model/analisis struktural model dilakukan untuk memastikan bahwa model struktural yang dibangun termasuk robust dan akurat. Evaluasi inner model dapat dilihat dari beberapa indikator yang meliputi: Koefisien determinasi $\left(\mathrm{R}^{2}\right)$ nilai ini menjelaskan seberapa besar variabel eksogen (independen/bebas) pada model mampu menerangkan variabel endogen (dependen/terikat). Hasil analisis Rsquare diperoleh nilai $\mathrm{R}^{2}$ kinerja hasil capaian $=0.3875$, Kemampuan bidan $=0.3063$, Kinerja aktivitas $=0.4569$. dilanjutkan dengan menghitung nilai Predictive Relevance $\left(\mathrm{Q}^{2}\right)$, Nilai dari Q-square dapat dihitung dengan perhitungan sebagai berikut : $\mathrm{Q}^{2}=1-(1-$ 0.3875) $(1-0.3063)(1-0.4569)=0.7692$. Berdasarkan hasil dari perhitungan Q-square dapat dilihat bahwa nilai Q-square sebesar 0.7692. karena nilai Q2 > 0, dapat disimpulkan bahwa model memiliki tingkat prediksi yang baik. Selanjutnya dapat dihitung juga nilai Goodness of Fit Index (GoF) dengan menggunakan rumus Tanenhaus (2004), dari hasil perhitungan tersebut dapat diperoleh nilai GOF index sebesar 0,4977 yang berarti goodnes of fit dari model ini adalah bagus/besar.

\section{PEMBAHASAN}

Self-leadership atau kepemimpinan diri merupakan serangkaian proses yang digunakan individu untuk mengendalikan perilaku mereka sendiri (Robbins SP. 2006). Strategi selfleadership merupakan kemampuan awal yang mempunyai pengaruh terhadap berbagai aspek yang dapat meningkatkan kinerja. Hasil penelitian ini menunjukkan bahwa strategi self leadership berpengaruh langsung maupun tidak langsung terhadap kinerja aktivitas maupun terhadap kinerja hasil capaian layanan bidan dalam deteksi dini penyimpangan pertumbuhan dan perkembangan anak, pengaruh tidak langsung tersebut dimediasi oleh kemampuan dalam deteksi dini penyimpangan pertumbuhan dan perkembangan anak. Kemampuan diri adalah kepercayaan individu bahwa ia dapat melakukan tugas tertentu dengan menerapkan kemampuannya secara benar (Wirawan 2013). Kemampuan tersebut tercermin dalam pengetahuan dan keterampilan bidak dalam melaksanakan kegiatan deteksi dini penyimpangan pertumbuhan dan perkembangan anak.

Pengaruh stategi self leadership baik langsung maupun melalui jaliur tidak langsung terhadap kinerja bidan karena berbagai strategi dari self-leadership mempunyai peranan masingmasing yang mempunyai pengaruh positif terhadap berbagai aspek yang dapat meningkatkan kinerja. Strategi tersebut meliputi: 
Strategi Pola Pikir Konstruktif (Constructive Thought Pattern Strategies), Strategi ini melibatkan kreasi dan proses berpikir yang konstruktif, dirancang untuk membantu formasi pola pikir yang konstruktif dan caracara yang positif mempengaruhi kinerja individu. Membangun kebiasaan atau pola konstruktif dan efektif dalam pemikiran kita (misalnya, kecenderungan untuk mencari peluang daripada hambatan yang tertanam dalam tantangan) dengan mengelola: keyakinan dan asumsi (beliefs and assumptions) melalui proses. (Jeffery, et al., 2012) melalui proses identifikasi dan pengubahan berbagai keyakinan yang keliru ini, individu dapat meminimalkan proses pemikiran yang disfungsional dan terlibat dalam proses kognisi yang lebih rasional dan efektif.Strategi pola pemikiran konstruktif ini terdiri dari: a) self observation, b) self goal setting, c) self reward, d) self punishment, e) self cueing (Manz and Sims 1997).

Strategi Imbalan Alamiah (Natural Reward Strategies), Strategi ini adalah strategi yang dilakukan dengan menciptakan reward yang alami yang ditujukan untuk mendapatkan penghargaan terhadap aktivitas yang dilakukan. Menurut (Manz and Sims, 1997) ada dua strategi yang dilakukan, yaitu dengan menciptakan features yang lebih menyenangkan pada aktivitas sehingga tugas-tugasnya sendiri menjadi reward yang bersifat alami. Selain itu dapat dengan cara memfokuskan perhatian pada tugas-tugas yang tidak menyenangkan tetapi ada aspek penghargaan. Kedua cara ini akan menciptakan perasaan kompeten dan meningkatkan motivasi instrinsik sehingga dapat meningkatkan kinerja. Strategi ini lebih memfokuskan pada aspek positif yang diberikan oleh tugas atau aktivitas.

Reward yang alami akan diperoleh dari insentif yang dibangun dari tugas itu sendiri. Strategi imbalan alami merupakan strategi yang dilakukan dengan menciptakan imbalan alami yang ditujukan untuk mendapatkan penghargaan terhadap aktivitas yang dilakukan. Ada dua strategi yaitu self-redesign of tasks, merupakan self redesign dari apa yang dilakukan dan bagaimana melakukan pekerjaan untuk meningkatkan tingkat penghargaan alami dalam pekerjaan. Natural reward merupakan bagian terpisah dari tugas itu sendiri (yaitu pekerjaan, seperti hobi hal ini menjadi imbalan) dari hasil kegiatan yang menyebababkan ada perasaan kompeten (a sense of competence), merasa self control (a sense of self-control), dan rasa tujuan (a sense of purpose). Redesign dari konteks pekerjaan anda (Redesign of the Context of your work) merupakan kegiatan mendesain ulang lingkungan sekitar pekerjaan atau mengubah waktu dan tempat kerja untuk meningkatkan manfaat alami yang berasal dari lingkungan terdekat (Yutthana, 2010).

Strategi berfokus Perilaku (Behavior Focused Strategies), Strategi terfokus pada perilaku dilaksanakan untuk meningkatkan kesadaran diri dalam memfasilitasi manajemen perilaku, terutama manajemen perilaku yang terkait dengan tugas-tugas yang dibutuhkan tetapi tidak menyenangkan. Strategi ini meliputi observasi diri, penentuan tujuan diri, memberikan imbalan diri sendiri, menghukum diri sendiri dan memberi petunjuk diri sendiri. Mengobservasi diri sendiri meliputi meningkatkan kesadaran diri ketika dan mengapa seseorang melakukan perilaku tertentu. Jenis kesadaran diri ini merupakan langkah pertama yang diperlukan untuk mengubah atau menghilangkan perilaku yang tidak efektif dan tidak produktif. Dengan mempergunakan informasi yang akurat mengenai perilaku dewasa ini dan level kinerja, seseorang akan dapat lebih efektif menentukan perilaku mengubah tujuan untuk diri sendiri. Perilaku yang terfokus pada strategi self-leadership dirancang untuk mendorong perilaku-perilaku positif sesuai harapan yang mengarah pada keluaran sukses, dan menekan perilaku-perilaku negatif yang tidak diharapkan yang mengarah pada kegagalan (Manz, et. al. 1997). Namun menghukum diri yang berlebihan, termasuk kritik diri yang keras dan realistis, dapat menyebabkan perasaan bersalah dan tidak mampu, hal ini harus dihindarkan (Jeffery, et al.,2012).

\section{KESIMPULAN DAN SARAN}

\section{Kesimpulan}

Strategi self-leadership merupakan faktor penting yang dapat meningkatkan berbagai aspek yang dapat berpengaruh terhadap peningkatan kinerja bidan dalam deteksi dini penyimpangan tumbuh kembang anak. Self-leadership yang tinggi seorang bidan akan memiliki persepsi yang baik terhadap kemampuan dirinya, sehingga mereka akan melaksanakan kegiatan/aktivitas dalam deteksi dini sesuai dengan jadwal dan kebutuhan anak. Aktivitas deteksi yang sesuai 
dengan jadwal dan kebutuhan anak anak dapat meningkatkan hasil capaian layanan bidan dalam deteksi dini penyimpangan tumbuh kembang anak.

\section{Saran}

Mengingat sebagian besar bidan masih memiliki kemampuan self-leadership dalam kategori cukup maka disarankan perlu adanya upaya peningkatan kemampuan self-leadership yang dapat dicapai melalui pelatihan maupun pembelajaran secara mandiri atau alamiah dengan pemberian motivasi, otonomi dan kesempatan pada bidan untuk dapat memimpin dirinya sendiri.

\section{REFERENSI}

Depkes, R.., 2007. Pedoman Pelaksanaan Stimulasi, Deteksi dan intervensi Dini Tumbuh Kembang Anak, Jakarta: Dirjen Pembinaan Kesehatan Masyarakat.

Dinas Kesehatan Kota Surabaya, 2013. Profil Dinas Kesehatan Kota Surabaya, Surabaya: Dinkes Kota Surabaya.

Dinas Kesehatan Kota Surabaya, 2012. Profil Dinas Kesehatan Kota Surabaya, Surabaya: Dinkes Kota Surabaya.

Dinas Kesehatan Kota Surabaya, 2010. Profil
Dinas Kesehatan Kota Surabaya, Surabaya: Dinkes Kota Surabaya.

Dinkes Propinsi Jawa Timur, 2012. Profil Dinas Kesehatan Propinsi Jawa Timur Surabaya, ed., Dinkes Propinsi Jawa Timur.

Jeffery D. Houghton, David Dawley, T.C.D., 2012. The Abbreviated Self-leadership Questionnaire (ASLQ)o Title. International Journal of Leadership Studies, Vol 7, pp.216-232.

Manz, Charles C and Sims, J., 1997. The New SuperleadershipLeading Others To Lead Themselves, San Francisco: BerretKoehler Publishers, Inc.

Robbins SP., 2006. Perilaku Organisasi Kontroversi, Aplikasi Edisi Baha., Jakarta: PT. Prehallindo.

Wirawan, 2013. Kepemimpinan Teori, Psikologi, Perilaku Organisasi, Aplikasi dan Penelitian, Jakarta,: PT Raja Grafindo Persada.

Yutthana C, 2010. an Examination of Selfleadership Performance Mecahanism model In Thai Private Organization,. The Journal of Behavioral Science, 5(1), pp.15-32. 